\title{
Organic geochemical characterization of the density fractions of a Permian torbanite
}

\author{
Zhiwen Han, Michael A. Kruge, John C. Crelling and B. Artur Stankiewicz \\ Department of Geology, Southern Illinois University, Carbondale, IL 62901, U.S.A.
}

\begin{abstract}
Two distinct organic components, the Botryococcus-related alginite (Reinschia) and the amorphous organic matrix, were isolated by high-resolution density gradient centrifugation (DGC) from a Permian torbanite (New South Wales, Australia). On the density profile, the alginite $(1.03-1.10 \mathrm{~g} / \mathrm{ml})$ and the matrix $(1.16-1.21 \mathrm{~g} / \mathrm{ml})$ appear to be two distinct peaks. With fluorescence microscopy, the alginite shows bright yellow to orange fluorescence and well-preserved algal structure, whereas the matrix has a reddish brown fluorescence of medium intensity. The $\mathrm{H} / \mathrm{C}$ and $\mathrm{O} / \mathrm{C}$ atomic ratios indicate that the alginite is equivalent to a Type I kerogen, whereas the matrix falls into the Type II kerogen category. The more "heavy" $\mathrm{O}$ and $\mathrm{S}$, and less "light" $\mathrm{H}$ content in the matrix also helps in explaining the higher density of the matrix relative to the alginite. Flash pyrolysis-GC/MS of the $\mathrm{CH}_{2} \mathrm{Cl}_{2}$-extracted density fractions shows that the pyrolyzates of both the alginite and the matrix are dominated by normal alk-1-enes and alkanes, which range up to $C_{31}$. However, these normal hydrocarbons are relatively more abundant in the alginite than in the matrix. The alginite also produced a $n-\alpha, \omega$-alkadiene series which was not detected in the matrix. Compared to the alginite, the matrix pyrolyzate is enriched in $\mathrm{C}_{19}-\mathrm{C}_{31}$ straight-chain aliphatics and aromatic, phenolic and hopanoid compounds, suggesting that the matrix was formed through incorporation of degraded algal material and humic matter. The higher Methylphenanthrene Index (MPI) value of the matrix pyrolyzates relative to the alginite indicates that the MPI is affected by organic matter type.
\end{abstract}

Key words-density gradient centrifugation (DGC), torbanite, Botryococcus-related alginite, organic matrix, flash pyrolysis-gas chromatography/mass spectrometry

\section{INTRODUCTION}

Torbanites are vitrinite-poor coals that macroscopically have a massive appearance and often show conchoidal fractures. The use of torbanites in the shale oil industry brought them into special economic and social prominence in the last century and earlier this century. Their occurrence also stimulated great scientific interest soon after the Scottish torbanite was discovered in 1850 . However, it took scientists nearly a century to recognize that torbanites were derived mainly from a single green alga comparable to the extant Botryococcus braunii (Thiessen, 1925; Blackburn and Templey, 1936; Belcher, 1955). Thereafter, understanding of the nature of the extant Botryococcus algae has been considered the key to the elucidation of the origin of torbanites and the related kerogens in oil source rocks. Therefore, investigations into the properties of the extant Botryococcus braunii have been conducted intensively and significant progress has been made (e.g. Maxwell et al., 1968; Wake and Hillen, 1981; Largeau et al., 1980; Dubreuil et al., 1989; Metzger et al., 1992). The resulting insights about the extant algae have been continuously applied to the fossil equivalents (e.g. Cane and Albion, 1971; Largeau et al., 1984, 1986; Derenne et al., 1988). However, torbanite is not petrographically homogeneous. In addition to the notable Botryococcus-related alginites, a major component is the amorphous to fine-grained matrix. Macerals derived from higher plants such as sporinites, detrital vitrinite and inertinite are also commonly present. Therefore, it is not surprising that the previous comparative studies between the extant Botryococcus algae and bulk samples of torbanites tended to be less than satisfactory.

The heterogeneity of torbanites was recognized and reported soon after the Scottish torbanite was found. However, because of the difficulty in separating the various components in torbanite, almost all previous chemical studies of torbanites were conducted on bulk samples instead of the individual components. To our knowledge, the first comparison of the algal body and the matrix in torbanite was done by Landais et al. (1993), using in situ transmission micro-Fourier transform-infrared spectroscopy.

Recently, with the successful application of the density gradient centrifugation technique to the separation of macerals in humic coals (Dyrkacz and Horwitz, 1982; Dyrkacz et al., 1984; Crelling, 1988, 1989), more attention has been focused on the characterization of the isolated density fractions of coals and kerogens (Senftle et al., 1986; Kruge et al., 1989, 1991; Kruge and Landais, 1992; Nip et al., 1988, 1989, 1992; Stankiewicz et al., 1993). In this paper the DGC technique was used to separate the various organic components in a Permian torbanite from 
New South Wales, Australia. Thereafter, elemental analysis and flash pyrolysis-gas chromatography/mass spectrometry (Py-GC/MS) were applied to the isolated density fractions.

\section{EXPERIMENTAL}

\section{Sample description}

The torbanite studied is from the sample collections in the Department of Geology, Southern Illinois University at Carbondale, and is of Permian age from New South Wales, Australia. In hand specimen, the torbanite is black and appears to be homogeneous with conchoidal fractures.

\section{Petrography}

Both polished blocks and crushed-particle pellets were prepared in accordance with the standard ASTM procedures (ASTM, 1987). Petrographic analyses including maceral composition, vitrinite reflectance measurement and photomicrography were performed by using a Leitz MPV II microscope, which is equipped with both white-light and bluelight (BG $12+$ BG 38) illumination systems.

\section{Density gradient centrifugation ( $D G C$ )}

The sample was crushed to $<75 \mu \mathrm{m}$ size in a ball mill and then extracted with $\mathrm{CH}_{2} \mathrm{Cl}_{2}$ in a sonicator. The extraction residues were treated with $20 \% \mathrm{HCl}$ for $24 \mathrm{~h}$ and then with $30 \% \mathrm{HF}$ for the same time period. Following this acid demineralization, cryogenic treatment was performed by immersing the sample in liquid nitrogen so that fractures along maceral boundaries could be induced due to the different coefficients of thermal expansion of the various macerals. Micronization was accomplished with a Garlock FMT jet mill in a nitrogen atmosphere. It was found that the cryogenic treatment significantly enhanced the efficiency of micronization. The micronized sample was separated into series of density fractions in a density range from 1.0 to $1.6 \mathrm{~g} / \mathrm{ml}$ with a Beckman $\mathbf{J} 2-21 \mathrm{M}$ centrifuge in accordance with published DGC procedures (Dyrkacz and Horwitz, 1982; Dyrkacz et al., 1984; Crelling, 1988). Part of each collected density fraction was made into pellets and examined with the reflected light microscope.

Because the microscopic examination revealed incomplete separation of the major components in the torbanite, a "high-resolution" DGC separation method was employed. In high-resolution DGC separation, the micronized sample was split into two portions by sink-float centrifugation at a single density determined by examining the standard DGC profile [Fig. 1(a)]. For the torbanite in this study, the sink-float cut point was chosen at $1.11 \mathrm{~g} / \mathrm{ml}$, which divided the profile into the alginite-dominated portion $(<1.11 \mathrm{~g} / \mathrm{ml})$ and the matrix-dominated portion $(>1.11 \mathrm{~g} / \mathrm{ml})$. Then each portion underwent a second DGC procedure, but over a narrower density range. Following the high-resolution separation, the purity of each density fraction was microscopically evaluated. The selected density fractions were extracted with $\mathrm{CH}_{2} \mathrm{Cl}_{2}$ a second time, removing all traces of bitumen, plus any soluble contaminants that might have been introduced during the sample processing.

\section{Elemental analysis}

Elemental analyses $(\mathrm{C}, \mathrm{H}, \mathrm{O}, \mathrm{N}$ and $\mathrm{S})$ of the isolated maceral fractions were made by Desert Analytics, Tucson, Ariz.

Flash pyrolysis-gas chromatography/mass spectrometry

Flash pyrolysis-gas chromatography/mass spectrometry (Py-GC/MS) was conducted with a CDS 120 pyroprobe, connected to an HP 5890 gas chromatograph (GC) with an HP 5970 Mass Selective Detector (MSD). The GC was equipped with a $25 \mathrm{~m}$ HP- 1 column $(0.2 \mathrm{~mm}$ i.d., film thickness $0.33 \mu \mathrm{m})$. The oven of the gas chromatograph was operated under the following program: isothermal for $5 \mathrm{~min}$ at $0^{\circ} \mathrm{C}$, temperature programmed at $5^{\circ} / \mathrm{min}$ to $300^{\circ} \mathrm{C}$, and then isothermal for $15 \mathrm{~min}$. The MS was operated in full scan mode $(50-550 \mathrm{Da}, 0.86 \mathrm{scans} / \mathrm{s}$, $70 \mathrm{eV}$ ionization voltage). The sample, contained in a quartz tube placed in the center of a platinum coil, was pyrolyzed at $610^{\circ} \mathrm{C}$ in a flow of helium. For each run, about $1.0 \mathrm{mg}$ of sample was used. The identification of the peaks was based on mass spectra, GC retention times, with reference to the U.S. National Bureau of Standards mass spectral library and literature (Radke et al., 1990; Douglas et al., 1991; Hartgers et al., 1992; Nip et al., 1992; Sinninghe Damsté et al., 1989, 1992a, b, 1993).

\section{RESULTS}

\section{Petrography}

Microscopically, both torbanite and cannel coal are characterized by a "porphyritic texture" with coarser-grained maceral phytoclasts (analogous to phenocrysts in igneous rocks) set in a fine-grained to amorphous matrix/groundmass (Han and Crelling, 1993). As shown in Plate $1(\mathrm{~A})$ and (B) this Permian torbanite indeed possesses such a texture with Reinschia (Botryococcus-related) telalginite phytoclasts $(43.4 \%)$ embedded in a uniform amorphous organic matrix $(34.2 \%)$. Other maceral phytoclasts include sporinite $(8.6 \%)$, cutinite $(0.9 \%)$, detrital vitrinite $(5.8 \%)$ and inertinite $(7.1 \%)$. The Reinschia telalginites are characterized by a bright yellow to orange fluorescence. They generally look like compressed sacs and possess well-preserved colonial cell structure. The relic structure is inherited from the original algae that occurred as hollow globes on which individual algal cells colonized [Plate 1(A)]. 


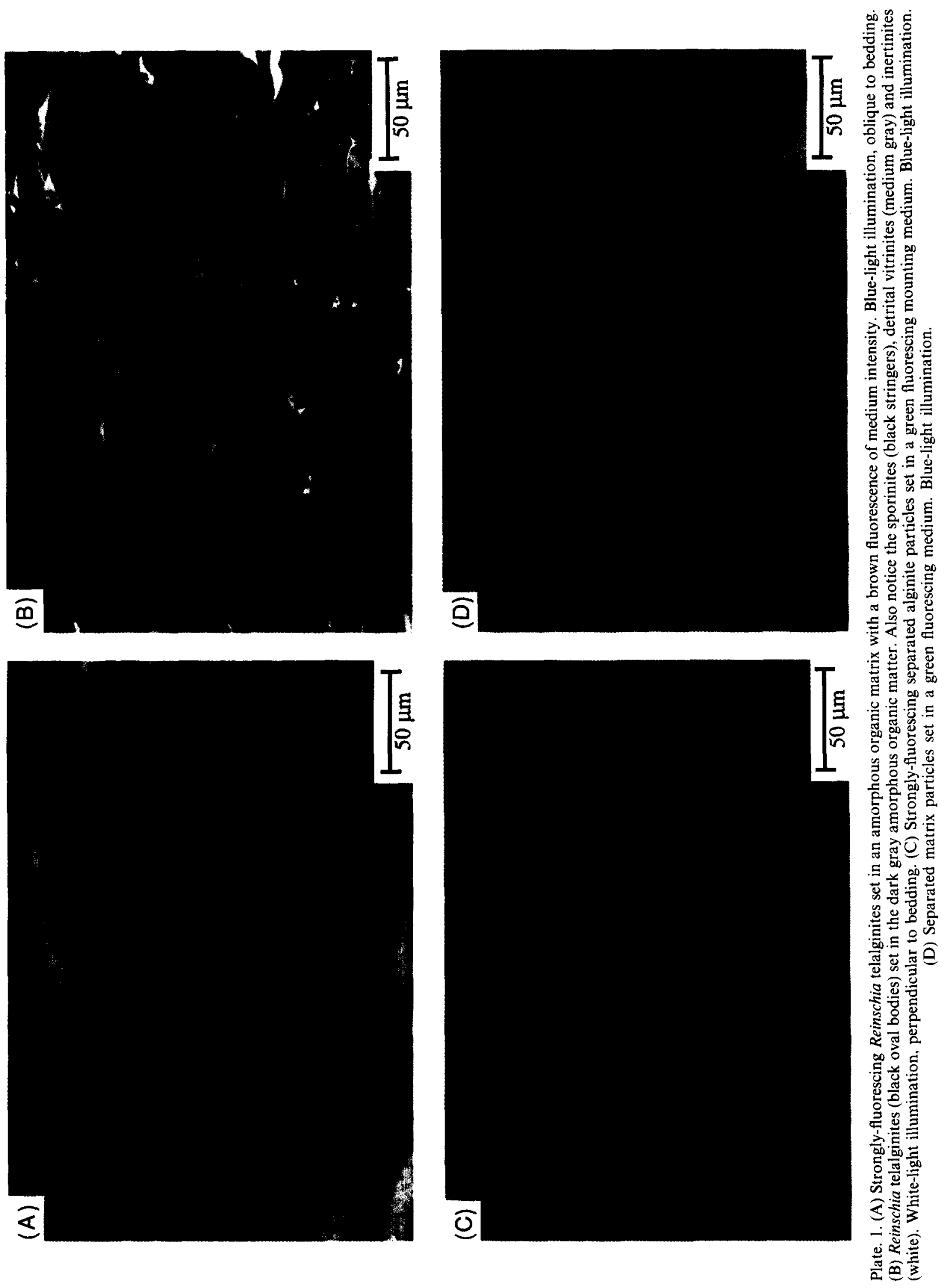




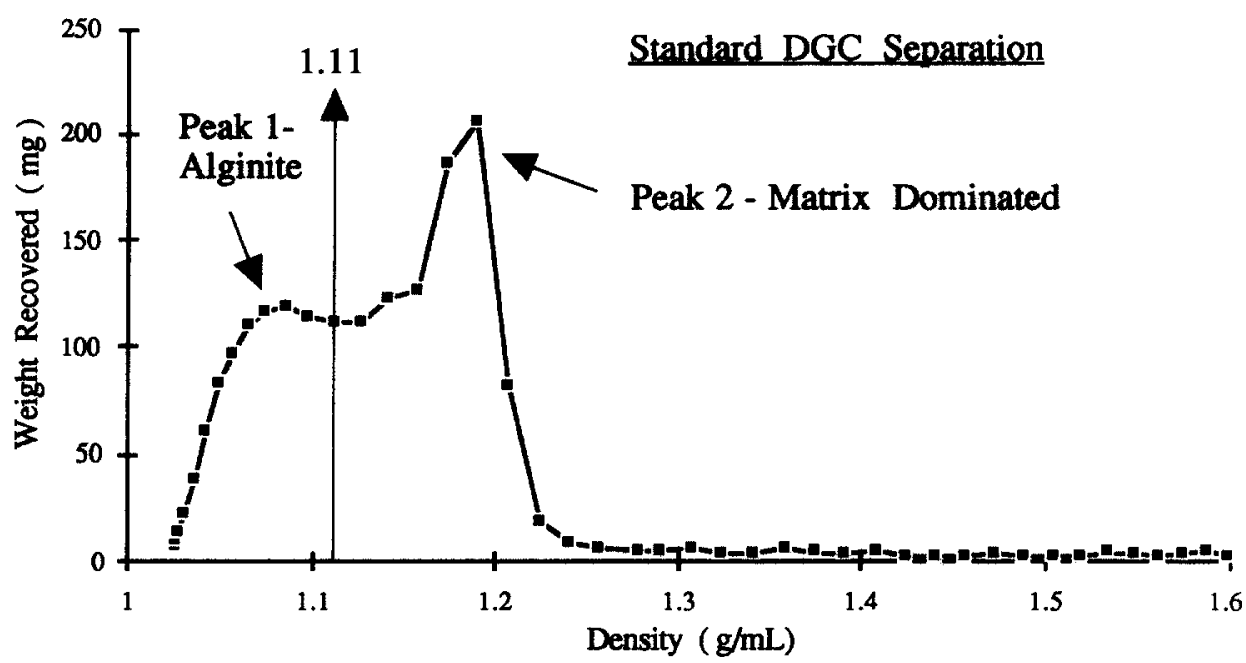

(a)

High Resolution DGC Separation

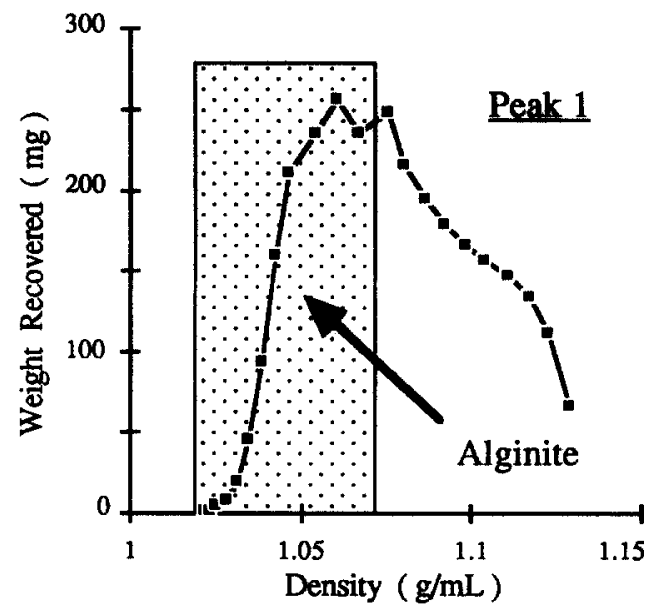

(b)

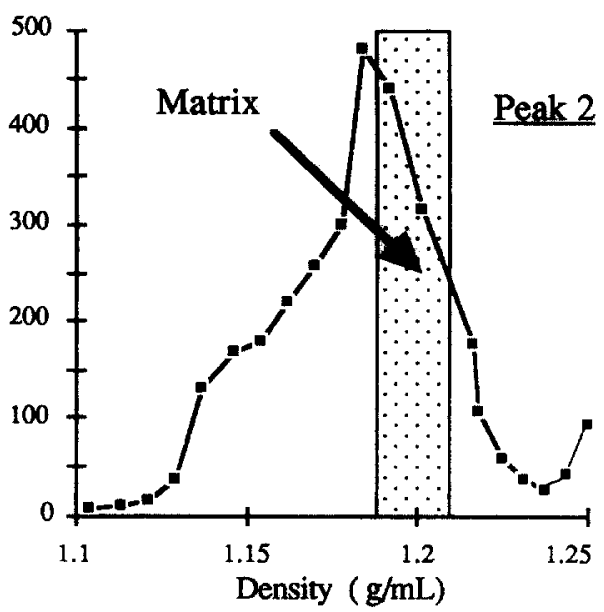

(c)

Fig. 1. Density gradient profiles of the torbanite. (a) Standard DGC separation of the whole torbanite, (b) high-resolution DGC separation of Peak 1 in Fig. 1(a) and (c) high-resolution DGC separation of Peak 2 in Fig. 1(a). Stippled portions indicate density ranges used in petrographic and chemical analyses.

The matrix is composed of amorphous organic matter throughout which is mixed with minor amounts of mineral matter, micrinite, vitrodetrinite and inertodetrinite. While its amorphous appearance and dark grey color under white light give it a superficial resemblance to desmocollinite, its brown to reddish fluorescence of medium intensity distinguishes it from the coexisting vitrinite particles.

The mean maximum reflectance $\left(R_{\max }\right)$ of the vitrinite particles was measured to be $0.34 \%$ (range from 0.3 to $0.4 \%$ ). Because the nearby humic coals at the sample location give a rank in the bituminouscoal range, the reflectance of vitrinite in the torbanite is clearly suppressed. Anomalously low reflectance is common where liptinite content is high (Hutton and Cook, 1980; Goodarzi, 1985).

\section{$D G C$ separation profiles}

When the recovered weights of the density fractions are plotted as a function of density (Fig. 1), it is shown that the density fractions of the torbanite mainly fall in a density range from 1.02 to $1.22 \mathrm{~g} / \mathrm{ml}$. Microscopic examination shows that the results of DGC separation are consistent with the petrographic composition of the torbanite. The two major components - alginite and matrix - appear as notable peaks at $1.03-1.10$ and $1.16-1.21 \mathrm{~g} / \mathrm{ml}$ respectively. While the sporinites are found between $1.10-1.15 \mathrm{~g} / \mathrm{ml}$, the vitrinite and inertinite are at densities above $1.2 \mathrm{~g} / \mathrm{ml}$. However, the maceral separation is incomplete. Each fraction is still a mixture of different macerals. The best result achieved is the 
Table 1. Elemental composition of the extracted density fractions of the torbanite

\begin{tabular}{lcccccccc}
\hline & $\mathrm{C}$ & $\begin{array}{c}\mathrm{H} \\
\text { (wt \%, dry, ash free) }\end{array}$ & $\mathrm{O}$ & $\begin{array}{c}\text { Ash } \\
\text { (wt \%) }\end{array}$ & $\mathrm{H} / \mathrm{C}$ & $\mathrm{O} / \mathrm{C}$ \\
\hline Alginite & 86.1 & 10.1 & 1.5 & 0.9 & 1.4 & 1.24 & 1.41 & 0.013 \\
Matrix & 82.1 & 6.9 & 6.8 & 1.9 & 2.3 & 2.74 & 1.01 & 0.062 \\
\hline
\end{tabular}

fractions at $1.02-1.05 \mathrm{~g} / \mathrm{ml}$, which are $90-95 \%$ of alginites mixed with $5-10 \%$ other components.

This separation of the various components in the torbanite was improved by a high-resolution DGC run. Based on the shape of the standard density gradient profile [Fig. 1(a)], the sample was centrifuged into two fractions at $1.11 \mathrm{~g} / \mathrm{ml}$ by sink-float. The low density fraction was composed mainly of alginite and the other was enriched in matrix. Then each of the two fractions was processed through a DGC run. The density ranges selected were $1.00-1.15 \mathrm{~g} / \mathrm{ml}$ for the alginite and $1.10-1.25 \mathrm{~g} / \mathrm{ml}$ for the matrix [see Fig. 1(b) and (c)].

Petrographic observation showed that the maceral separation had been significantly enhanced with the high resolution DGC procedure. As shown in Fig. 1(b), the stippled fractions $(1.02-1.07 \mathrm{~g} / \mathrm{ml})$ are composed of visually pure alginites [Plate $1(\mathrm{C})$ ]. The stippled fractions $(1.18-1.21 \mathrm{~g} / \mathrm{ml})$ in Fig. 1(c) are composed of very homogeneous matrix [Plate 1(D)]. The unshaded fractions in both Fig. 1(b) and (c) are mixtures of different components.

\section{Elemental composition}

The results of elemental analysis are given in Table 1, showing that the alginite fraction has a higher hydrogen content, slightly higher carbon content but lower oxygen, sulfur and nitrogen contents relative to the matrix fraction. The high $\mathrm{H} / \mathrm{C}$ atomic ratio and very low $\mathrm{O} / \mathrm{C}$ atomic ratio of the alginite indicate that the alginite has a highly aliphatic chemical structure and is comparable to a Type I kerogen (Tissot and Welte, 1984). Whereas the $\mathrm{H} / \mathrm{C}$ and $\mathrm{O} / \mathrm{C}$ atomic ratios illustrate that the matrix falls into the Type II kerogen category. The $\mathrm{H} / \mathrm{C}$ and $\mathrm{O} / \mathrm{C}$ atomic ratios also indicate the torbanite has entered a mature kerogen stage, adjacent to the oil generation line. This is in disagreement with the low vitrinite reflectance $\left(0.34 \% R_{\max }\right)$ of the torbanite, showing that the reflectance has been suppressed.

\section{Flash pyrolysis-GC/MS}

Flash pyrolysis-GC/MS analysis was performed on both the alginite and matrix fractions, as well as the extracted residue of the bulk torbanite sample. As revealed by the total ion current traces (Fig. 2), the pyrolyzates of both the alginite and the matrix are dominated by $n$-alkanes and $n$-alk-1-enes ranging from $C_{6}$ to $C_{31}$. The alginite fraction also produced a series of $n-\alpha, \omega$-alkadienes, which were not detected in the matrix. Other pyrolysis products include alkylbenzenes, alkylnaphthalenes, alkylphenanthrenes, alkylindenes, alkylphenols, alkylthiophenes, hopenes and hopanes. Generally, the pyrolyzates of alginite are characterized by more straight chain aliphatics, while the matrix produced relatively more aromatic hydrocarbons, heteroatomic compounds, hopanes and hopenes (Figs 2 and 3).

Straight chain aliphatics. As shown by the total ion currents (Fig. 2), straight chain aliphatics are the dominant compounds in the pyrolyzates of both the alginite and matrix. However, there are also some differences in straight chain aliphatics between the alginite and matrix:

(1) In addition to the $n$-alkanes and $n$-alk-1-enes, the alginite produced a series of $n-\alpha, \omega$-alkadienes ranging from $C_{7}$ to $C_{28}$, which were not detected in the matrix.

(2) Generally, the alginite pyrolyzates are more enriched in straight chain aliphatics with terminal double bonds. Besides the $n-\alpha, \omega$-alkadienes, the concentration of $n$-alk-l-enes is higher than that of $n$-alkanes in the alginite pyrolysis products. In contrast, the matrix pyrolyzates show a higher concentration of $n$-alkanes over $n$-alk-1-enes. Figure 2 generally reveals that from $C_{6}$ to $C_{31}$, each $n$-alk-1ene peak is almost always stronger than the $n$-alkane peak for the alginite. For the matrix, the $n$-alkene peaks are stronger from $\mathrm{C}_{6}$ to $\mathrm{C}_{11}$, and the $n$-alkane peaks are dominated from $\mathrm{C}_{12}$ to $\mathrm{C}_{31}$.

(3) The matrix also produced more and longer chain aliphatics ranging from $C_{19}$ to $C_{31}$ relative to the alginite, which are the characteristic feature of the higher plant lipids like cutinite (Nip et al., 1989).

Hopenes and hopanes. Hopenes and Hopanes are significant compounds present in the pyrolysis products of the matrix (Fig. 2). Trace amounts of hopanes/enes were also detected in the alginite pyrolyzates. The $m / z 191$ ion chromatograms (Fig. 4) reveal 11 major hopanes and hopenes present in both the alginite and matrix pyrolyzates, with carbon numbers ranging from $\mathrm{C}_{27}$ to $\mathrm{C}_{31}$. Their names are specified in the caption of Fig. 4. Hopanoid identifications were based on mass spectral and retention time data. The hopane/ene isomer assignments came from the literature reference (Sinninghe Damsté $e t$ al., 1992b). The presence of hopanoids in the pyrolyzates of the doubly-extracted alginite and matrix demonstrates the incorporation of such structures into the macerals and, by implication, the role of anaerobic bacteria in early diagenesis. The relative richness of hopanes/enes in the matrix pyrolyzates indicates a higher contribution from bacteria to the matrix.

Aromatic hydrocarbons. The aromatic hydrocarbons are the next most abundant compounds in the pyrolyzates of both the matrix and the alginite. The 


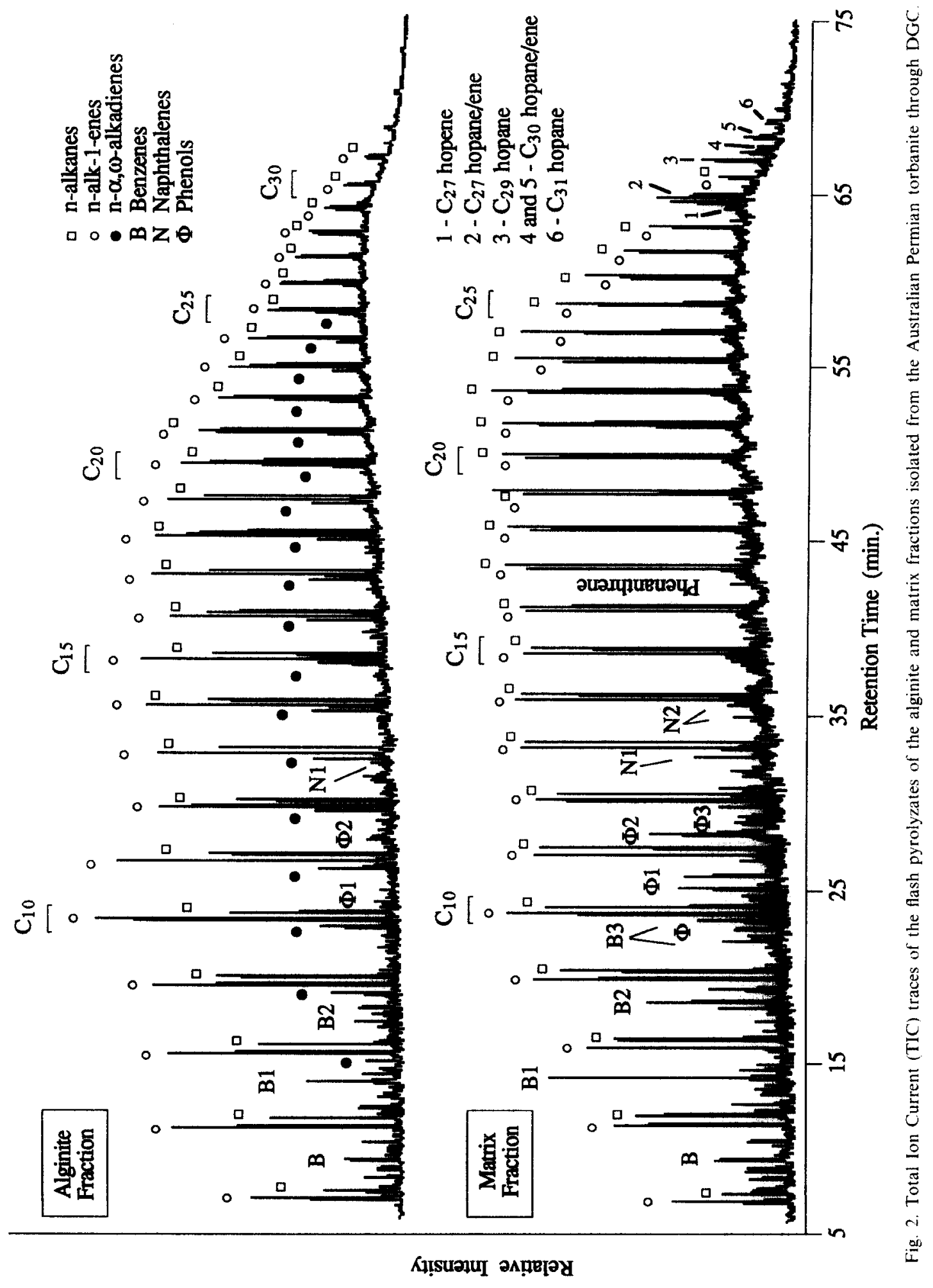




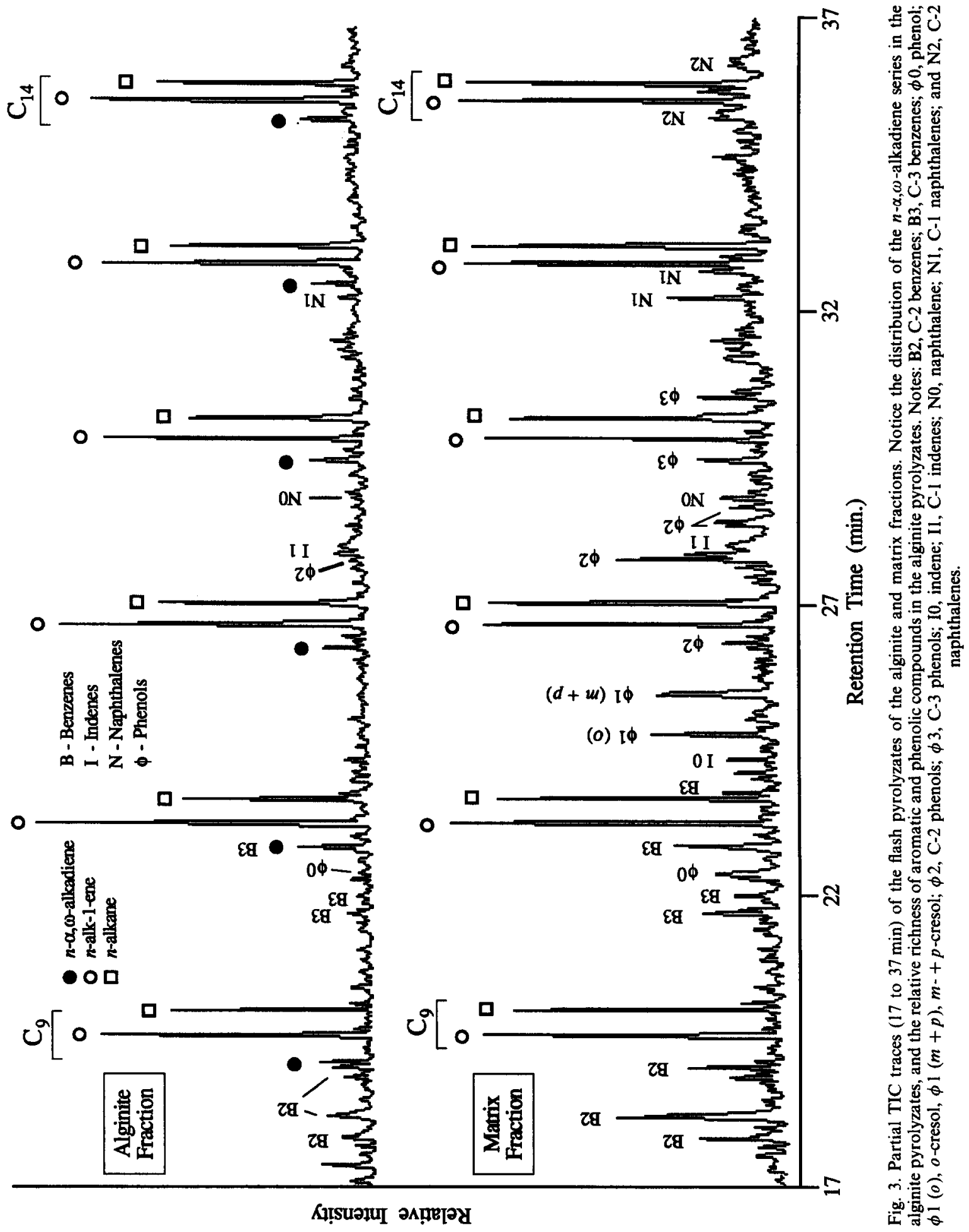


major classes of aromatic compounds include benzene, naphthalene, indene, phenanthrene and anthracene, as well as their alkylated derivatives. Pyrene, fluoranthene, chrysene and their alkyl derivatives were also detected, but were significantly less abundant. Aromatic hydrocarbons are more abundant in the pyrolysis products of the matrix than in the alginite (Fig. 3).

The summed mass chromatograms of $m / z 178$ and 192 (Fig. 5) illustrate the distribution of phenanthrene and anthracene as well as their methyl derivatives. It is interesting to note that anthracenes, while uncommon in petroleum and rock extracts, were seen in the pyrolysis products. Figure 5 also indicates that the 1 and 9-methylphenanthrenes of the alginite are notably more abundant than those of the matrix. The distribution of methylphenanthrenes in the extracted organic matter has been found to be related to the geothermal evolution of source rocks, and the difference in concentration of the various methylphenanthrenes has been quantitatively expressed as a Methylphenanthrene Index [MPI, 1.5(2-methyl + 3-methyl)/(Phenanthrene + 1-methyl +9-methyl)], and used as an indicator of the geo-
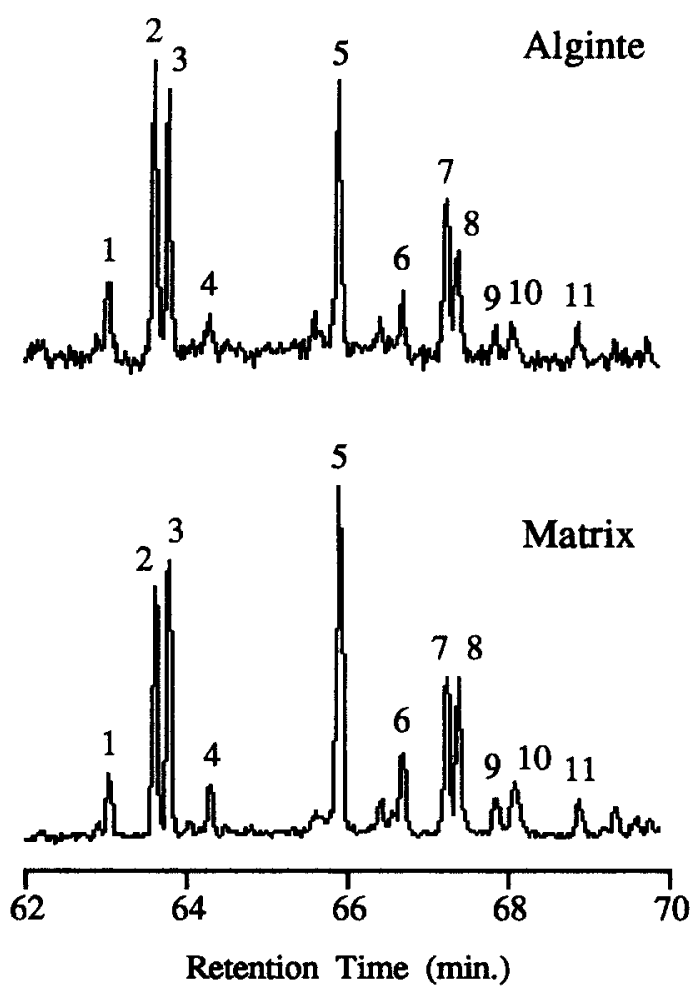

Fig. 4. Mass chromatograms of $m / z$ 191 showing the distribution of hopanes and hopenes in the pyrolyzates of the alginite and matrix. Notes: 1, trisnorhopene; 2, 22,29,30. trisnorhop-17,21-ene; 3, 17 $\alpha(\mathrm{H})$-22,29,30-trisnorhopane; 4 , $17 \beta(\mathrm{H})-22,29,30$-trisnorhopane; $5, \quad 17 \alpha(\mathrm{H}), 21 \beta(\mathrm{H})-30-$ norhopane; $6,17 \beta(\mathrm{H}), 21 \alpha(\mathrm{H})$-30-norhopane; 7 , hopene; 8 $17 \alpha(\mathrm{H}), 21 \beta(\mathrm{H})$-hopane; 9 , hopene; $10,17 \beta(\mathrm{H}), 21 \alpha(\mathrm{H})$ hopane; $11,17 \alpha(\mathrm{H}), 21 \beta(\mathrm{H})$-homohopane.

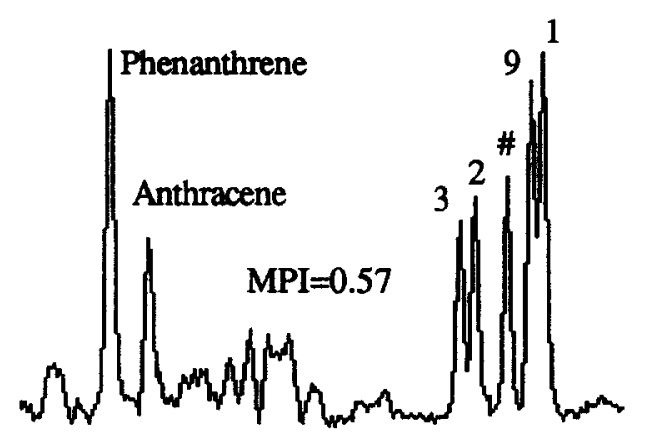

(Alginite)

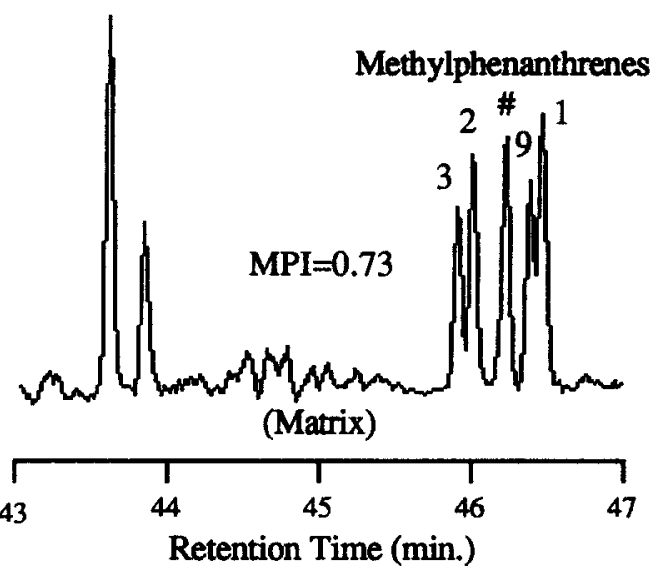

Fig. 5. Summed mass chromatograms of $m / z 178+192$ showing the distribution of the phenanthrene/anthracene and methylphenanthrenes and methylanthracene (\#) in the pyrolyzates of the alginite and matrix.

thermal maturity (Radke, 1987). The MPI calculated from kerogen pyrolyzates was also previously used as a geothermal parameter and found to be highly variable (Requejo et al., 1992). In this research, the MPI values calculated from the pyrolysis products show that the MPI of the alginite is 0.57 , the matrix is 0.73 , indicating a variation of the MPI values due to organic matter type. Because the pyrolysis done by Requejo et al. (1992) was based on bulk kerogen samples, the highly variable MPI values might be caused by the variation of the bulk kerogen in organic composition.

Phenol and alkylphenols. Phenol and alkylphenols are present as significant pyrolysis products in the matrix fractions. Minor amounts of phenolic compounds were also detected in the alginite pyrolyzates (Fig. 3). The greater importance of phenols in the matrix pyrolyzates is corroborated by its higher atomic oxygen content. The phenolic pyrolysis products were shown to be the distinguishing compounds in the vitrinites from high volatile bituminous coals (Sentfle et al., 1986; Hatcher et al., 1992). It was also found that the abundance of the $-\mathrm{OH}$ group in the matrix of a French torbanite was much higher than in the alginite (Landais et al., 


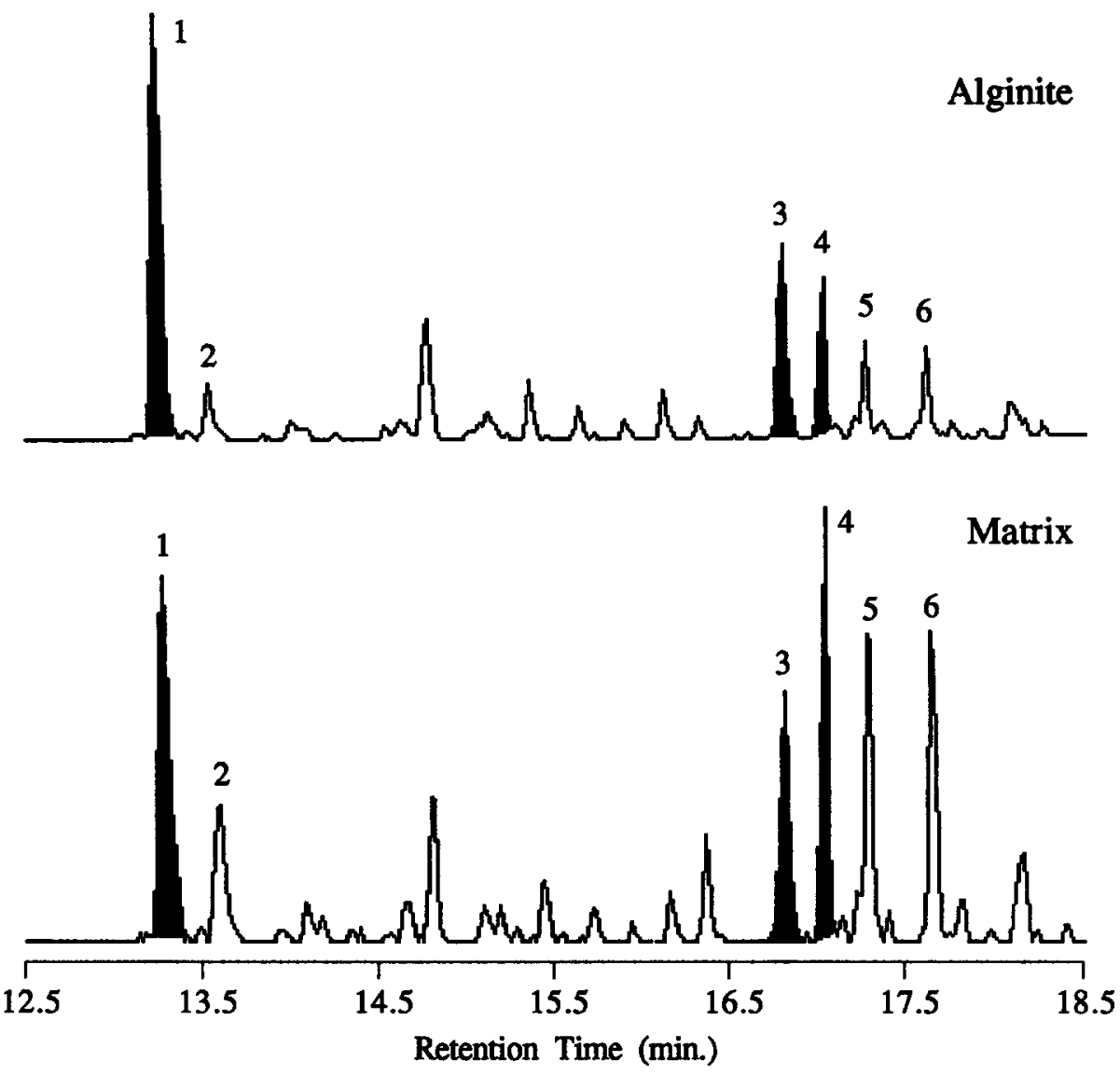

Fig. 6. Summed mass chromatogram of $m / z 97+98+111+112$ showing the distribution of the $C_{1}-C_{2}$ alkylthiophenes in the pyrolyzates of the alginite and matrix. Notes: 1, 2-methylthiophene; 2, 3-methylthiophene; 3, 2-ethylthiophene; 4, 2,5-dimethylthiophene; 5, 2,4-dimethylthiophene; 6, 2,3-dimethylthiophene.

1993). Therefore, the higher concentration of phenols in the pyrolysis products of the matrix relative to the alginite demonstrates significant contribution from lignin-derived organic matter to the matrix.

Alkylthiophenes. Alkylthiophenes are present as trace components in the pyrolyzates of both the alginite and matrix, which agrees with the overall low sulfur contents of the samples (Table 1). Figure 6 shows the distribution of $C_{1}$ and $C_{2}$ alkylthiophenes and reveals some significant differences between the alginite and the matrix. The alkylthiophenes of the alginite are dominated by 2-methylthiophene, while $\mathrm{C}_{2}$ alkylated thiophenes are more abundant in the matrix. According to Sinninghe Damsté et al. (1989), the variety of alkylated thiophenes in the pyrolyzates of kerogens are related to the carbon skeletons of the sulfur-containing moieties in the kerogens. The 2methyl, 2-ethyl and 2,5-dimethylthiophenes are considered to be derived from the linear alkylthiophene moieties, while the 3-methylthiophene, 2,3 and 2,4-dimethylthiophenes are thought to be from branched, isoprenoid or steroid alkylthiophene moieties. It was also found that highly aliphatic Type
I kerogen pyrolyzates contain thiophenes with predominantly linear carbon skeletons, and Type III kerogens produced more non-linear alkylthiophenes (Eglinton et al., 1992). It can be clearly seen in Fig. 6 that the alginite, a typical Type I kerogen, produced more alkylated thiophenes with linear carbon skeletons (the shaded peaks). However, the matrix pyrolyzates contain more non-linear alkylthiophenes such as 2,3- and 2,4-dimethylthiophene. The linear alkylthiophenes are also significant in the matrix pyrolysis products. Therefore, the higher concentration of alkylthiophenes with both linear structure and non-linear structures of the matrix indicates a chemical nature intermediate between the Type I and Type III kerogens, which is also demonstrated by the $\mathrm{H} / \mathrm{C}$ and $\mathrm{O} / \mathrm{C}$ atomic ratios.

\section{DISCUSSION}

Microscopically, the torbanite is very heterogeneous. The various organic components are well mixed. In particular, the two major components: the alginite and matrix were tightly bound to each other. 
Therefore, cryogenic treatment is particularly helpful in liberating the alginite and matrix from each other. Through a high-resolution DGC procedure, visually pure alginite and matrix were isolated. On the one hand, the successful separation enabled us to study the diagenetic interrelation between very different types of organic matter: the alginite and matrix. isolated from the same torbanite sample, which experienced an identical post-depositional geological history, yet are still distinctly different. On the other hand, the effectiveness of the DGC separations were also confirmed by the petrographic and chemical data as described above. It is interesting to note that higher density of the matrix can be explained by the elemental composition, less of "light" $\mathrm{H}$ but more of "heavy" $O$ and $S$.

Morphologically, the alginites in the torbanite [Plate I(A), (B) and (C)] are comparable to the extant Botryococcus braunii which is a widespread green alga living in brackish to fresh water (Blackburn and Temperley, 1936). The elemental and Py-GC/MS data further indicate that the alginite is characterized by a highly aliphatic nature. The coexistence of series of $n$-alkanes, $n$-alk-1-enes and $n$ - $x, \omega$-alkadienes demonstrates that the alginite generally has a polymeric structure built mainly upon straight chain aliphatics

The extant Botryococcus braunii algae are well known for their biosyntheses of hydrocarbons. Based on the structure of the synthesized hydrocarbons, three modern races of Botryococcus braunii have been recognized. Race $\mathrm{A}$ is characterized by production of $\mathrm{C}_{23}-\mathrm{C}_{31} n$-alkadienes and trienes dominated by 27,29 and 31 members, while race $B$ produces $C_{31} C_{37}$ polymethylated triterpenes, the botryococcenes. Race $\mathrm{L}$ produces hydrocarbons consisting mainly of lycopadiene $\left(\mathrm{C}_{40} \mathrm{H}_{78}\right)$ (Metzger et al.. 1992). The predominance of straight chain aliphatics in the alginite pyrolyzates might suggest that the precursors of the Reinschia alginite in the torbanite could have a hydrocarbon-synthesizing behavior similar to the extant race $A$ Botryococcus braunii. In addition, no trace of the botryococcenes or lycopadienes or similar compounds were identified in the pyrolyzates of the torbanite.

The predominance of the $n$-alkanes and $n$-alk- 1 enes in its pyrolyzates reveals that the matrix also has a generally aliphatic nature. Considering the petrographically amorphous nature of the matrix, it is tempting to conclude that matrix is generally formed by the biodegradation of algal bodies. However, microscopic observation does not support this idea. It shows that the alginite and the matrix are two distinct categories in the torbanite. There is no morphological transition between them.

Therefore, it seems impossible for the algal bodies to decompose into the amorphous matrix. Furthermore, the morphological integrity of the alginites indicate that the algae were almost entirely preserved [Plate 1(A)]. However, biodegradation of the alginite is still apparent. In Huorescence mode, the alginites are not homogeneous. The algal cell walls are brightly fluorescing. but the algal cells have a darker fluorescence because the algal cells are enriched in chemical components such as starch and proteins which are very vulnerable to bacteria (Blackburn and Templey. 1936). The bacterial modification is also indicated by the trace hopanoid compounds in the alginite pyrolyzates

Although the algal bodies were not physically destroyed by degradation. it is possible that the biochemical modifications of the algae could cause some algal material, mainly aliphatics, to separate from the algae and participate the formation of the matrix by incorporating with the humic matter and clays. The relative richness in long chain aliphatics $\left(C_{10}, C_{3}\right)$ and phenolic compounds in the matrix pyrolyzates also suggests a contribution of higher plant lipids and lignin-derived material. The higher concentration of hopenes and hopanes in the matrix suggests a significant contribution by anaerobic bacteria, In addition. the strong distribution of alkylated thiophenes with both linear and non-linear carbon skeletons also suggest that the matrix has multiple precursors

\section{CONCLUSIONS}

Based on all the above petrographic and geochemical data, the following conclusions are drawn:

(1) The torbanite is dominated by a strongly fluorescing Botryococcus-related telalginite (Reinschia) and a uniform organic matrix with a reddish brown fluorescence of medium intensity. Minor amounts of detrital vitrinite and inertinite as well as sporinite and cutinite are also present.

(2) The two major components-alginite and matrix--in the torbanite were isolated through a high-resolution density gradient centrifugation (DGC) procedure. Petrographic examination demonstrated that the isolated alginite and matrix fractions were homogeneous and visually pure. Because the alginite and the matrix are tightly bound to each other, the cryogenic treatment is a crucial step to liberate them from each other during sample crushing

(3) The results of elemental analysis show that the alginite is equivalent to a Type I kerogen whereas the matrix falls into the Type II kerogen category. $\mathrm{H} / \mathrm{C}$ and $\mathrm{O} / \mathrm{C}$ atomic ratios also suggest the torbanite has a maturity just above the onset of oil generation. The elemental analysis data also demonstrate that the higher density of the matrix can be explained by its relative richness in "heavy" atoms-O and $\mathrm{S}$.

(4) Both the alginite and the matrix pyrolyzates are dominated by straight-chain alk-1-enes and alkanes over a wide molecular weight ranging up to $C_{31}$. The alginite also produced an $n-x, \omega$-alkadiene series which was not detected in the matrix pyrolyzate. The 
matrix pyrolyzates contain relatively more $\mathrm{C}_{19}-\mathrm{C}_{31}$ aliphatics derived from higher plant lipids.

(5) Compared with the alginite, the pyrolysis products of the matrix contain more aromatic, phenolic and hopanoid compounds. They are also characterized by higher non-linear alkylbenzenes. The higher MPI value of the matrix relative to the alginite indicates that the MPI is affected by organic matter type.

(6) The petrographic and chemical results suggest that the matrix was formed in an anaerobic environment through incorporation of bacterially degraded algal material with degraded material from higher plants.

Acknowledgements-The authors thank Mr Bill Huggett, Mr David F. Bensley and Ms Corliss Thies (Department of Geology, Southern Illinois University) for their technical assistance in sample preparation and data processing.

\section{REFERENCES}

American Society for Testing and Materials (ASTM) (1987) Annual Book of ASTM Standards: Part 26: Gaseous Fuels; Coal and Coke; Atmospheric Analysis. ASTM, Philadelphia.

Belcher J. H. (1955) Biochemical evidence of the affinities of Botryococcus. New Phytologist 54, 81-83.

Blackburn K. B. and Temperley B. N. (1936) Botryococcus and the algal coals. Part I: A reinvestigation of the alga Botryococcus Braunii Kutzing; Part II: Boghead Controversy and the Morphology of the Boghead Algae. Trans. Roy. Soc. Edinb. 58, 841-854 and 855-870.

Cane R. F. and Albion P. R. (1971) The phytochemical history of torbanites. J. Proc. R. Soc. New South Wales 104, 31-37.

Crelling J. C. (1988) Separation and characterization of coal macerals including pseudovitrinite. Ironmaking Proc.AIME 43, 351-356.

Crelling J. C. (1989) Separation and characterization of coal macerals: accomplishments and future possibilities. $\mathrm{Am}$. Chem. Soc. Div. Fuel Chem. Prepr. 34, 249-255.

Derenne S., Largeau C., Casadevall E., Tegelaar E. and de Leeuw J. W. (1988) Relationships between algal coals and resistant cell wall biopolymers of extant algae as revealed by Py-GC-MS. Fuel Process. Technol. 20, 93-101.

Douglas A. G., Sinninghe Damsté J. S., Fowler M. G., Eglinton T. I. and de Leeuw J. W. (1991) Unique distributions of hydrocarbons and sulphur compounds by flash pyrolysis from the fossilized alga Gloeocapsomorpha prisca, a major constituent in one of four Ordovician kerogens. Geochim. Cosmochim. Acta 55, 275-291.

Dubreuil C., Derenne S., Largeau C. and Berkaloff C. (1989) Mechanism of formation and chemical structure of Coorongite-I. Role of the resistant biopolymer and of the hydrocarbons of Botryococcus braunii. Ultrastructure of Coorongite and its relationship with torbanite. Org. Geochem. 14, 543-553.

Dyrkacz G. R. and Horwitz E. P. (1982) Separation of coal macerals. Fuel 61, 3-12.

Dyrkacz G. R., Bloomquist C. A. A. and Ruscic L. (1984) High-resolution density variations of coal macerals. Fuel 63, 1367-1374.

Eglinton T. I., Sinninghe Damsté J. S., Pool W., de Leeuw J. W., Eijkel and Boon J. J. (1992) Organic sulphur in macromolecular sedimentary organic matter. II. Analysis of distributions of sulphur-containing pyrolysis products using multivariate techniques. Geochim. Cosmochim. Acta 56, 1545-1560.
Goodarzi F. (1985) Organic petrology of Hat Creek coal deposit No. 1, British Columbia. Int. J. Coal Geol. 5, 377-396.

Han Z. and Crelling J. C. (1993) Observations on the petrographic composition of cannel and boghead coals. Proceeding of 7 th International Conference on Coal Science, Vol. I, pp. 144-147. Banff, Alberta.

Hartgers W. A., Sinninghe Damsté J. S. and de Leeuw U. W. (1992) Identification of C2-C4 alkylated benzenes in flash pyrolyzates of kerogens, coals and asphaltenes. J. Chromatogr. 606, 211-220.

Hatcher P. G., Faulon J., Wenzel K. A. and Cody G. D. (1992) A structural model for lignin-derived vitrinite from high-volatile bituminous coal (coalified wood). Energy Fuel 6, 813-820

Hutton A. C. and Cook A. C. (1980) Influence of alginite on the reflectance of vitrinite from Joadja, NSW, and some other coals and oil shales containing alginite. Fuel $59,711-714$.

Kruge M. A., Crelling J. C., Hippo E. J. and Palmer S. R (1991) Aspects of sporinite chemistry. Org. Geochem. 17, 193-204.

Kruge M. A and Landais P. (1992) Artificial maturation of coal and maceral concentrates: Saturate and polyaromatic molecular markers. Am. Chem. Soc. Div. Fuel Chem. Prepr. 37, 1595-1600.

Kruge M. A., Crelling J. C. and Rimmer S. M. (1989) Organic geochemical and petrographic analysis of pure macerals from the Ohio Shale. In 1988 Eastern Oil Shale Symposium (Edited by Lazar D. J.), pp. 411-417. Institute for Mining and Minerals Research, Lexington, $\mathrm{Ky}$.

Landais P., Rochdi A., Largeau C. and Derenne S. (1993) A chemical characterization of torbanites by transmission micro-FTIR spectroscopy. Origin and extant of compositional heterogeneities. Geochim. Cosmochim. Acta. 57, 2529-2539.

Largeau C., Casadevall E. and Berkaloff C. (1980) Sites of accumulation and composition of hydrocarbons in Botry. ococcus braunii. Phytochemistry 19, 1043-1051.

Largeau C., Casadevall E., Kadouri A. and Metzger P. (1984) Formation of Botryococcus-derived kerogensComparative study of immature torbanites and of the extant alga Botryococcus braunii. Org. Geochem. 6, $327-332$

Largeau C., Derenne S., Casadevall E., Kadouri A. and Sellier N. (1986) Pyrolysis of immature torbanite and of the resistant biopolymer (PRB A) isolated from extant alga Botryococcus braunii. Mechanism for the formation and structure of torbanite. In Advances in Organic Geochemistry 1985 (Edited by Leythaeuser D. and Rullkötter J.). Org. Geochem. 10, 1023-1032. Pergamon Press, Oxford.

Maxwell J. R., Douglas A. G., Eglinton G. and McCormick A. (1968) The Botryococcenes-hydrocarbons of novel structure from the alga Botryococcus braunii, Kutzing. Phytochemistry 7, 2157-2171.

Metzger P., Largeau C. and Casadevall E. (1992) Lipids and macromolecular lipids of the hydrocarbon-rich microalga Botryococcus braunii. Chemical structure and biosynthesis. Geochemical and biotechnological importance. In Progress in the Chemistry of Organic Natural Products (Edited by Herz W. et al.), Vol. 57, pp. 1-70. Springer, New York.

Nip M., de Leeuw J. W. and Crelling J. C. (1992) Chemical structure of bituminous coal and its constituent maceral fractions as revealed by flash pyrolysis. Energy Fuels 6 , $125-136$.

Nip M., de Leeuw J. W. and Schenck P. A. (1988) The characterization of eight maceral concentrates by means of Curie point pyrolysis-gas chromatography and Curie point pyrolysis-gas chromatographymass spectrometry. Geochim. Cosmochim. Acta 52, $637-648$. 
Nip M., de Leeuw J. W., Schenck P. A., Windig W., Muezelaar H. L. and Crelling J. C. (1989) A flash pyrolysis and petrographic study of cutinite from the Indiana paper coal. Geochim. Cosmochim. Acta 53, 671-683.

Radke M. (1987) Organic geochemistry of aromatic hydrocarbons. Advances in Petroleum Geochemistry, Vol. 2, pp. 141-206. Academic Press, London.

Radke M., Garrigues P. and Willsch H. (1990) Methylated bicyclic and tricyclic aromatic hydrocarbons in crude oils from the Handil field, Indonesia. Org. Geochem. 15, $17-34$.

Requejo A. G., Gray N. R. and Freund H. (1992) Maturation of petroleum source Rocks. 1. Changes in kerogen structure and composition associated with hydrocarbon generation. Energy Fuel 6, 203-214.

Senftle J. T., Larter S. R., Bromley B. W. and Brown J. H. (1986) Quantitative chemical characterization of vitrinite concentrates using pyrolysis-gas chromatography. Rank variation of pyrolysis products. Org. Geochem. 9, 345-350.

Sinninghe Damsté J. S., Eglinton T. I. and de Leeuw J. W. (1992a) Alkylpyrroles in a kerogen pyrolysate: Evidence for abundant tetrapyrrole pigments. Geochim. Cosmochim. Acta 56, 1743-1751

Sinninghe Damsté J. S., De Las Heras F. X. C and De Leeuw J. W. (1992b) Molecular analysis of sulphur-rich brown coals by fiash pyrolysis-gas chromatography-mass spectrometry. J. Chromatogr, 607, 361-376.

Sinninghe Damsté J. S., Eglinton T. I., de Leeuw J. W. and Schenck P. A. (1989) Organic sulphur in macromolecular sedimentary organic matter: I. Structure and origin of sulphur-containing moieties in kerogen, asphaltenes and coal as revealed by flash pyrolysis. Geochim. Cosmochim. Acta 53, 873-889.

Sinninghe Damsté J. S., De Las Heras X. C., Van Bergen P. F. and de Leeuw J. W. (1993) Characterization of Tertiary Catalan lacustrine oil shales: Discovery of extremely organic sulphur-rich Type I kerogens. Geochim. Cosmochim. Acta 57, 389-415.

Stankiewicz B. A., Kruge M. A. and Crelling C. J. (1993) Geochemical characterization of Maceral Concentrates from Herrin No. 6 Coal (Illinois Basin) and Lower Toarcian Shale Kerogen (Paris Basin). Bull. Centres Rech. Explor. -Prod. Elf-Aquitaine. In press.

Thiessen R. (1925) Origin of the boghead coals. U. S. Geol Surv. Prof. Papers 132-I, 121-135.

Tissot B. P. and Welte D. H. (1984) Petroleum Formation and Occurrence, 2nd edition. Springer, New York.

Wake L. V. and Hillen L. W. (1981) Nature and hydrocarbon content of blooms of the alga Botryococcus braunii occurring in Australian freshwater lakes. Aust. J. Mar. Freshwater Res. 32, 353-367. 